\title{
Erratum to: Root distribution of under-planted European beech (Fagus sylvatica L.) below the canopy of a mature Norway spruce stand as a function of light
}

\author{
Matjaž Čater $\cdot$ Primož Simončič
}

Published online: 29 January 2010

(C) Springer-Verlag 2010

Erratum to: Eur J Forest Res

DOI 10.1007/s10342-009-0352-9

In the original publication the authors' family names were presented as given names and vice versa. The names in this erratum are correct.

The online version of the original article can be found under doi:10.1007/s10342-009-0352-9.

M. Čater $(\bowtie) \cdot$ P. Simončič

Slovenian Forestry Institute, Večna pot 2,

1000 Ljubljana, Slovenia

e-mail: matjaz.cater@gozdis.si 